Arq. Bras. Med. Vet. Zootec., v.73, n.2, p.367-376, 2021

\title{
Strategic ventilation reduces non-ventilated contralateral lung injury induced by one-lung ventilation in rabbits
}

[Ventilação estratégica reduz lesão pulmonar contralateral não ventilada induzido pela ventilação pulmonar unilateral em coelhos]

\author{
H.J. Liu ${ }^{1}$, J. Jin ${ }^{1}$, D.D. Huang ${ }^{2}$
}

\begin{abstract}
${ }^{1}$ Zhoupu Hospital Affiliated to Shanghai University of Medicine \& Health Sciences - Shanghai, China
${ }^{2}$ South Branch of the Sixth Hospital affiliated Shanghai Jiao Tong University - Shanghai, China
\end{abstract}

\begin{abstract}
One lung ventilation (OLV) often results in trauma to the unventilated contralateral lung. This study aims to evaluate the effects of different OLV regimens on the injury of the unventilated contralateral lung to identify the best conditions for OLV. Forty rabbits were divided into five groups: a sham group, OLV group I (fraction of inspired oxygen $\left(\mathrm{F}_{\mathrm{I}} \mathrm{O}_{2}\right) 1.0$, tidal volume $(\mathrm{VT}) 8 \mathrm{~mL} / \mathrm{kg}$, respiratory rate $(\mathrm{R}) 40$ breaths/min and inspiratory/expiratory ratio (I:E) $1: 2)$, OLV group II $\left(\mathrm{F}_{\mathrm{I}} \mathrm{O}_{2}=1.0\right.$, VT $8 \mathrm{~mL} / \mathrm{kg}, \mathrm{R} 40$ breaths/min, I:E 1:2, and positive end-expiratory pressure (PEEP) $5 \mathrm{~cm} \mathrm{H}_{2} \mathrm{O}$ ), OLV group III $\left(\mathrm{F}_{\mathrm{I}} \mathrm{O}_{2} 1.0\right.$, VT $6 \mathrm{~mL} / \mathrm{kg}, \mathrm{R} 40$ breaths $/ \mathrm{min}, \mathrm{I}: \mathrm{E} 1: 2$ and PEEP $\left.5 \mathrm{~cm} \mathrm{H}_{2} \mathrm{O}\right)$ and OLV group IV $\left(\mathrm{F}_{\mathrm{I}} \mathrm{O}_{2} 0.8\right.$, VT $6 \mathrm{~mL} / \mathrm{kg}, \mathrm{R}$ 40 breaths/min, I:E 1:2 and PEEP $5 \mathrm{~cm} \mathrm{H}_{2} \mathrm{O}$ ). Animals from all OLV groups received two-lung ventilation (TLV) to establish a baseline, followed by one of the indicated OLV regimens. The rabbits in the sham group were intubated through trachea and ventilated with fresh air. Arterial blood gas samples were collected, lung injury parameters were evaluated, and the concentrations of TNF- $\alpha$ and IL-8 in bronchoalveolar lavage fluid (BALF) and pulmonary surfactant protein A (SPA) in the unventilated lung were also measured. In OLV group I, the unventilated left lung had higher TNF- $\alpha$, IL-8 and lung injury score but lower SPA than the ventilated right lung. In OLV groups I to III, the concentrations of TNF- $\alpha$, IL-8 and lung injury score in the left lung decreased but SPA increased. No differences in these parameters between OLV groups III and IV were observed. Strategic ventilation designed for OLV groups III and IV reduced OLV-induced injury of the non-ventilated contralateral lung in rabbits.
\end{abstract}

Keywords: one-lung ventilation, acute lung injury, strategic ventilation

\section{RESUMO}

Ventilação pulmonar unilateral (OLV) frequentemente resulta em trauma no pulmão contralateral não ventilado. Este estudo visa avaliar os efeitos de diferentes regimes de OLV sobre a lesão do pulmão contralateral não ventilado para identificar as melhores condições para OLV. Quarenta coelhos foram divididos em cinco grupos: um grupo falso, OLV grupo I (fração de oxigênio inspirado (FIO2) 1.0, volume corrente (VT) $8 \mathrm{~mL} / \mathrm{kg}$, frequência respiratória $(R) 40$ respirações $/ \mathrm{min}$ e relação inspiração/expiração (I:E) 1:2), OLV grupo II (FIO2=1.0, VT $8 \mathrm{~mL} / \mathrm{kg}, R \quad 40$ respirações/min, I:E 1:2, e pressão positiva expiratória final (PEEP) $5 \mathrm{~cm} \mathrm{H2O}$ ), OLV grupo III (FIO2 1.0, VT 6mL/kg, R 40 respirações/min, I:E 1:2 e PEEP $5 \mathrm{~cm} \mathrm{H2O}$ ) e OLV grupo IV (FIO2 0.8, VT 6mL/kg, R 40 respirações/min, I:E 1:2 e PEEP $5 \mathrm{~cm} \mathrm{H2O)}$. Os animais de todos os grupos OLV receberam ventilação nos dois pulmões (TLV) para estabelecer uma linha de base, seguida por um dos regimes OLV indicados. Os coelhos do grupo falso foram intubados através da traqueia e ventilados com ar fresco. Amostras de gases no sangue arterial foram coletadas, parâmetros de lesão pulmonar foram avaliados e as concentrações de TNF- $\alpha$ e IL-8 no fluido de lavagem bronco alveolar (BALF) e proteína A do surfactante pulmonar (SPA) no pulmão não ventilado também foram medidas. No grupo OLV I, o pulmão esquerdo não ventilado tinha maior índice de TNF- $\alpha$, IL-8 e lesão pulmonar, mas menor SPA do que o pulmão

Recebido em 24 de setembro de 2020

Aceito em 18 de dezembro de 2020

E-mail: zp_liuhj@sumhs.edu.cn 
direito ventilado. Nos grupos OLV I a III, as concentrações de TNF- $\alpha$, IL-8 e a pontuação de lesão pulmonar no pulmão esquerdo diminuíram, mas o SPA aumentou. Não foram observadas diferenças nestes parâmetros entre os grupos OLV III e IV. A ventilação estratégica projetada para os grupos OLV III e IV reduziu a lesão induzida por OLV do pulmão contralateral não ventilado em coelhos.

Palavras-chave: ventilação de um pulmão, lesão pulmonar aguda, ventilação estratégica

\section{INTRODUCTION}

One-lung ventilation (OLV) is carried out to allow a clearer view during thoracic surgical procedures (Liu et al., 2017) and to protect the normal lung from hemorrhage and abscess (Campos, 2002; Benumof, 1985). However, previous studies have shown that OLV has a number of drawbacks, such as induction of arteriovenous shunt, hypoxemia, and acute lung injury (ALI) (Eguchi et al., 2014; Kozian et al., 2008; Kallet and Matthay, 2013; Karzai and Schwarzkopf, 2009). Several studies have shown that the injury in the non-ventilated lung is greater than the one in the ventilated lung, although there are also studies reporting the opposite findings (Lohser and Slinger, 2015). Therefore, there is an imperative need to identify the ventilation regimes that can maintain the advantages of OLV but reduce the OLV-induced injury to both, the ventilated lung and the unventilated contralateral lung.

Strategic ventilation, also called protective ventilatory approach, defined as the adjustment of the mode of ventilation, respiratory parameters and pharmacological application, has been developed to improve the outcomes, while minimizing the lung injury during ventilation (Keszler, 2017; Brower, et al., 2000; BrunBuisson et al., 2004; Dellinger et al., 2004). OLV-induced lung injury is influenced by several factors, including tidal volume (VT), positive end-expiratory pressure (PEEP), and fraction of inspired oxygen $\left(\mathrm{F}_{\mathrm{I}} \mathrm{O}_{2}\right)$.

Traditional approaches include a relatively high VT in the range of $10-12 \mathrm{~mL} / \mathrm{kg}$ and zero PEEP to overcome hypoxemia during OLV (Brodsky and Fitzmaurice, 2001; Brodsky, 2005). However, some studies have shown that a low VT achieved favorable outcomes in OLV (Brower et al., 2000; Amato et al., 1998). It is not clear whether changes of the parameters such as VT, PEEP and/or $\mathrm{F}_{\mathrm{I}} \mathrm{O}_{2}$ in the OLV regimen ameliorate the injury of the non-ventilated contralateral lung during OLV. In the present study, we hypothesized that reduced VT and increased PEEP could ameliorate the OLVinduced injury to the unventilated contralateral lung. Based on this hypothesis, our study is designed to identify appropriate regimens of volume-controlled ventilation (VCV) to minimize lung injury during OLV.

\section{MATERIAL AND METHODS}

Healthy purebred male New Zealand white rabbits (20-months old, weighing $2.5-2.8 \mathrm{~kg}$ ) were obtained from our Experimental Animals Institute. All rabbits were housed in a room, maintained at $22 \pm 1^{\circ} \mathrm{C}$, a relative humidity of 50 $\pm 5 \%$ and a $12 \mathrm{~h}$-light/dark cycle. Food and water were available ad-libitum. Rabbits were acclimated to this new environment for one week before initiating the experimental procedure.

A total of 40 rabbits were divided randomly into 5 groups ( $\mathrm{n}=8$ per group): a sham group, OLV group I $\left(\mathrm{F}_{1} \mathrm{O}_{2} 1.0\right.$, VT $8 \mathrm{~mL} / \mathrm{kg}$, respiratory rate (R) 40 breaths/min and inspiratory/expiratory ratio (I:E) 1:2), OLV group II $\left(\mathrm{F}_{\mathrm{I}} \mathrm{O}_{2} 1.0\right.$, VT $8 \mathrm{~mL} / \mathrm{kg}$, R 40 breaths $/ \mathrm{min}$, I:E 1:2 and PEEP 5 $\left.\mathrm{cm} \mathrm{H}_{2} \mathrm{O}\right)$, OLV group III $\left(\mathrm{F}_{\mathrm{I}} \mathrm{O}_{2} 1.0\right.$, VT $6 \mathrm{~mL} / \mathrm{kg}$, R 40 breaths/min, I:E $1: 2$ and PEEP $5 \mathrm{~cm} \mathrm{H}_{2} \mathrm{O}$ ) and OLV group IV $\left(\mathrm{F}_{\mathrm{I}} \mathrm{O}_{2} 0.8\right.$, VT $6 \mathrm{~mL} / \mathrm{kg}, \mathrm{R} 40$ breaths/min, I:E $1: 2$ and PEEP $5 \mathrm{~cm} \mathrm{H}_{2} \mathrm{O}$ ). Rabbits were anesthetized with an auricular vein injection of pentobarbital sodium $(35 \mathrm{mg} / \mathrm{kg}$; Shanghai Green Analysis of Chemical Technology Co., Shanghai, China), and then placed on an operating table in the supine position. Heart rate (HR) and mean arterial pressure (MAP) were measured with a multifunctional biological signal acquisition system (BL-420E'; Taimeng Company, Chengdu, Sichuan, China) via femoral artery catheterization.

After infusion with $1 \mathrm{~mL}$ lidocaine (2\%; Shanghai Harvest Pharmaceutical Co., Ltd., Shanghai, China), tracheotomy was performed aseptically at the level of $2-3^{\text {rd }}$ tracheal cartilage through a midline incision on the neck. 
Following an intravenous injection of vecuronium $(0.15 \mathrm{mg} / \mathrm{kg}$; Zhejiang Xianju Medical Co., Ltd., Zhejiang, China), the trachea was intubated with a $3.0 \mathrm{~mm}$ uncuffed endotracheal tube (Telefiex Medical, NC, USA) to a depth of $4 \mathrm{~cm}$ (Kuipers et al., 2012). Rabbits were then treated with the following ventilation settings, $\quad \mathrm{F}_{\mathrm{I}} \mathrm{O}_{2} \quad 1.0, \quad \mathrm{VT} \quad 10 \mathrm{~mL} / \mathrm{kg}, \quad \mathrm{R} \quad 40$ breaths/min and I:E 1:2, with a HX3000S small animal ventilation machine (Taimeng Company, Chengdu, China) for $30 \mathrm{~min}$. as the baseline TLV. The rabbits in the sham group were intubated through the trachea, ventilated with fresh air, and MAP was measured throughout the procedure.

OLV of the right lung was established by inserting the tube into the right main bronchus, while the left lung was observed through a fiberscope (BF-1T260 intubation fiberscope; OLYMPUS MEDICAL SYSTEMS CORP., Japan) through a $0.5 \times 0.5 \mathrm{~cm}^{2}$ hole between the 6 th and 7 th ribs of the left thoracic wall, to confirm the effectiveness of the OLV. To simulate the surgical position, the rabbits were turned to the right-lateral position. TLV was administered for $30 \mathrm{~min}$. after the OLV procedure in different groups (i.e., different $\mathrm{F}_{\mathrm{I}} \mathrm{O}_{2}$, VT and PEEP for $3 \mathrm{~h}$ ). At the end of the experiment, cardiac arrest (CA) was induced by an intravenous injection of $10 \%$ potassium chloride, and the lungs were removed for pathological analysis.

During the whole procedure, the room temperature was set at $26-28^{\circ} \mathrm{C}$ to maintain the rectal temperature of the rabbits at $37-38^{\circ} \mathrm{C}$. Anesthesia was maintained by administering $30 \%$ pentobarbital sodium at $10 \mathrm{mg} / \mathrm{h}$ after tracheotomy and vecuronium at $1 \mathrm{mg} / \mathrm{kg} / \mathrm{h}$ dose. Normal saline $(0.9 \%)$ was infused at $10 \mathrm{~mL} / \mathrm{kg} / \mathrm{h}$ dose continuously throughout the procedure. Phenylephrine (3-10 $\mu \mathrm{g} / \mathrm{kg} / \mathrm{min})$ (Shanghai Harvest Pharmaceutical Co. Ltd.) was administered when MAP fell below $60 \mathrm{mmHg}$ for longer than $15 \mathrm{~min}$, and TLV was terminated if oxygen saturation $\left(\mathrm{SaO}_{2}\right)$ dropped below $80 \%$ for longer than 5 min during the OLV period.

Arterial blood gas parameters including $\mathrm{pH}$, partial pressure of oxygen $\left(\mathrm{PaO}_{2}\right)$, partial pressure of carbon dioxide $\left(\mathrm{PaCO}_{2}\right)$ and $\mathrm{SaO}_{2}$, were measured at the following four time points: at the onset of the procedure, $30 \mathrm{~min}, 2 \mathrm{~h}$ and 3.5 $\mathrm{h}$ after the onset of the procedure. These time points were equivalent to the initial stage of TLV, initial stage of OLV, $90 \mathrm{~min}$ after the onset of OLV and termination of OLV in different groups.

Sections of the tissues of the upper parts of the bilateral lungs of each rabbit from all study groups were fixed in $10 \%$ phosphate-buffered formalin, embedded in paraffin, sectioned and stained with H\&E. Lung injury was estimated semi-quantitatively, and morphological pathological changes were observed under a light microscope $(\times 400)$. Specifically, the collapse of the lung, formation of alveolar wall hyaline membrane, neutrophil infiltration, aggregation and alveolar congestion, and hemorrhage were examined. The quantification criteria were set as previously detailed (Tremblay and Slutsky, 2006; Saddy et al., 2010); 1 for normal lung or very slight injury, 2 for mild injury $(<25 \%), 3$ for moderate injury $(25 \%-50 \%), 4$ for severe injury $(50 \%-75 \%)$, and 5 for the most serious damage $(>75 \%)$. The average value from four different parts of each lung was used as the lung injury score.

Bronchoalveolar lavage fluid (BALF) was collected by lavaging the lungs 3 times with $5 \mathrm{~mL}$ of phosphate buffered solution (PBS) at $4{ }^{\circ} \mathrm{C}$ and centrifuging it at $1500 \times \mathrm{g}$ for $10 \mathrm{~min}$ and cryopreserved the supernatant at $-80^{\circ} \mathrm{C}$ for further analysis. The concentration of TNF- $\alpha$ and IL- 8 in BALF, and the pulmonary SPA in lung tissues were determined with enzyme-linked immunosorbent assay (ELISA). Any experimental rabbit which had one of the following was excluded from this study: 1) accidental death; 2) lower than $40 \%$ recovery of BALF of the upper lung; and 3) deployment of TLV for more than six times during the course of an OLV.

All continuous data were expressed as the mean \pm standard deviation (mean $\pm \mathrm{SD}$ ), and the ratio data were expressed as N. All data were analyzed with the Wilcoxon rank sum test (MannWhitney U test). Quantitative variables were analyzed using two-tailed Student's test, and categorical variables were analyzed by $\chi^{2}$ test or Fisher's exact test, as appropriate. Two-tailed P values $<0.05$ were deemed statistically significant. All statistical analyses were performed using the software package SPSS 


\section{Liu et al.}

(version 19.0.0, SPSS Inc., Chicago, Illinois, IBM, New York, NY).

\section{RESULTS}

The flow chart shown in Figure 1 depicts the entire procedure of this study. We started this study with a total of 40 rabbits. Two from OLV group I and one from group III were excluded from the experiment due to $<40 \%$ recovery of
BALF and serious arterial hemorrhage, respectively. The rabbits in each group had comparable weight $(p>0.05)$, and the frequency of TLV during the OLV procedure to avoid $\mathrm{SaO}_{2}$ $<80 \%$, also showed no significant difference ( $p>0.05$, Table 1). In addition, the use of phenylephrine to maintain MAP $\geq 60 \mathrm{~mm} \mathrm{Hg}$ among the OLV groups was similar $(p>0.05$, Table 1).

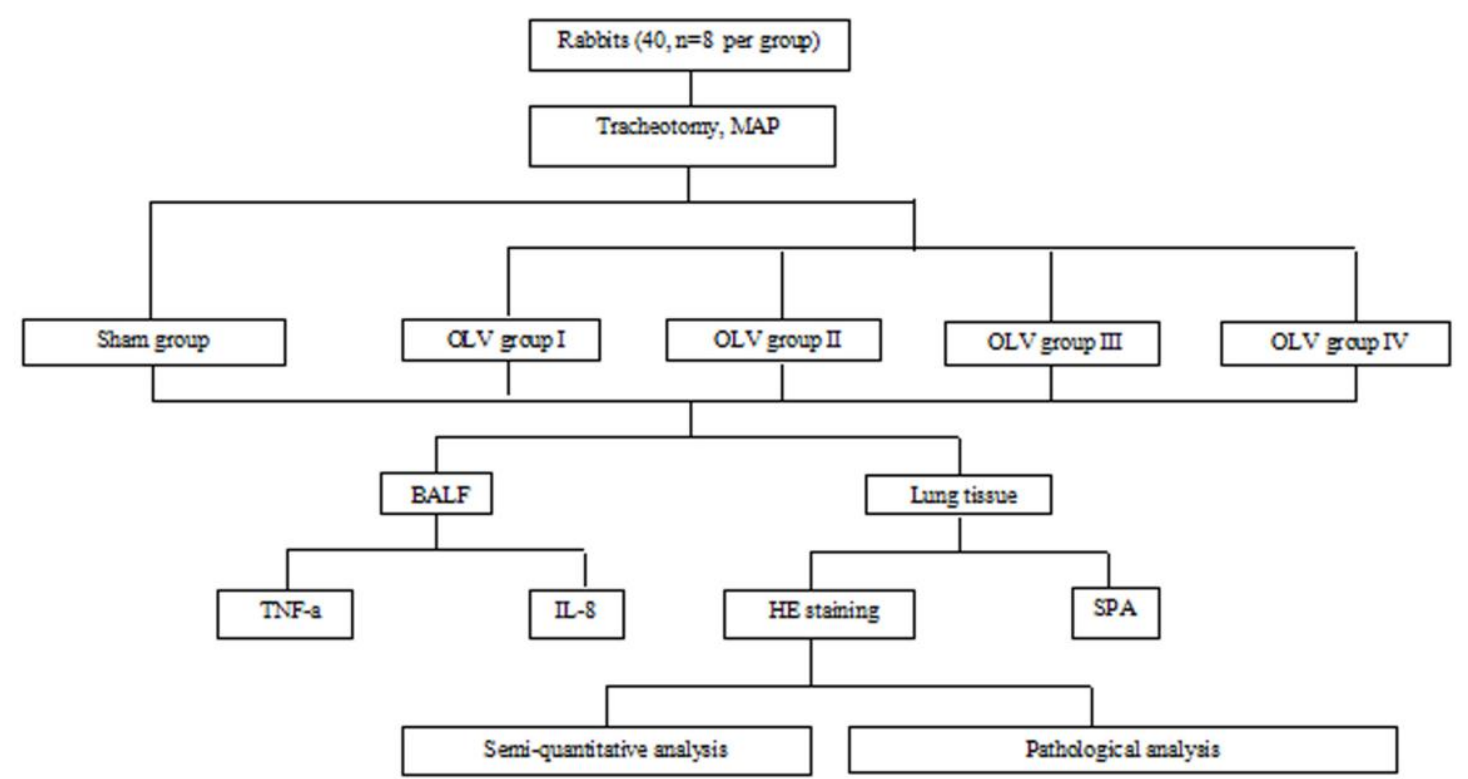

Figure 1. Flow diagram showing the entire procedure of this study. A total of 40 rabbits were divided randomly into 5 groups ( $n=8$ per group): a sham group, OLV group I, OLV group II, OLV group III and OLV group IV. Then, rabbits were subject to determination of inflammatory cytokines and pathological changes.

Table 1. Comparison of general parameters among five groups

\begin{tabular}{lccccc}
\multicolumn{1}{c}{ Variable } & $\begin{array}{c}\text { Sham } \\
\text { group }\end{array}$ & OLV group I & OLV group II & OLV group III & OLV group IV \\
\hline Weight $(\mathrm{kg})$ & $2.66 \pm 0.43$ & $2.57 \pm 0.39$ & $2.63 \pm 0.48$ & $2.71 \pm 0.36$ & $2.69 \pm 0.51$ \\
RTO (n) & $/$ & $3.83 \pm 0.75$ & $3.14 \pm 1.21$ & $3.38 \pm 0.74$ & $3.50 \pm 1.07$ \\
$\begin{array}{l}\text { Usage of } \\
\text { phenylephrine (ug }\end{array}$ & 0 & $1561.53 \pm 245.46$ & $1438.39 \pm 227.88$ & $1536.22 \pm 249.28$ & $1549.67 \pm 233.65$ \\
\hline
\end{tabular}

Values are presented as mean \pm SD ( $n=8$ /group except $n=6$ for OLV I and 7 for OLV III); RTO= Recovery of TLV during OLV.

We next compared the arterial blood gas parameters between the different groups. We found no differences in $\mathrm{pH}$ and $\mathrm{PCO}_{2}$ values between these five groups $(p>0.05)$ (Figure 2A and $\mathrm{B})$. The $\mathrm{PaO}_{2}$ at $2 \mathrm{~h}$ and $3.5 \mathrm{~h}$ after the onset of trial in the sham group were lower than that in each of the OLV groups (all $P<0.01$, Figure 2C). The $\mathrm{SaO}_{2}$ at $2 \mathrm{~h}$ after the onset of trial in OLV group I was lower than that in all other OLV groups and the sham group (all $P<0.05$, Figure 2D). 



Figure 2. Comparison of arterial blood gas parameters among five groups. A total of 40 rabbits were divided randomly into 5 groups ( $\mathrm{n}=8$ per group): a sham group, OLV group I, OLV group II, OLV group III and OLV group IV. Arterial blood gas parameters were measured at the following four time points (0.5 h, $2 \mathrm{~h}$ and $3.5 \mathrm{~h}$ ), including (A) $\mathrm{pH}$, (B) $\mathrm{PCO}_{2}$, (C) $\mathrm{PaO}_{2}$ and (D) $\mathrm{SaO}_{2}$.

The concentrations of TNF- $\alpha$, IL- 8 in BALF and SPA in lung tissues were measured by ELISA. Each specimen was tested 4 times, and the average of these four values was used for the final analysis. As shown in Table 2, OLV group I had higher concentrations of TNF- $\alpha$ and IL-8 in BALF and a higher lung injury score in the nonventilated left lung than in the ventilated right lung (all $P<0.05$ ). On the contrary, OLV group I had a lower concentration of SPA in the left lung than that in the right $(P<0.05)$. These observations suggested that in the group I, the non-ventilated lung suffered more injury than the ventilated lung.

We also found that the concentration of TNF- $\alpha$ and IL-8 in BALF and the lung injury score in the left lung significantly decreased and the concentration of SPA significantly increased from OLV group I to III (all $P<0.05$ ) (Table 2). Order of the severity of lung injury caused by the regimens used in these OLV groups is group I > group II > group III. However, between groups III and IV, no significant difference was observed in the concentrations of TNF- $\alpha$, IL- 8 , SPA and injury scores in the left lung $(P>0.05)$ (Table 2), suggesting that a lower $\mathrm{F}_{\mathrm{I}} \mathrm{O}_{2}$ did not attenuate the OLV-induced lung injury.

These values of group IV were also higher than those of the sham group (all $P<0.05$ ); however, it had a lower concentration of SPA, compared to the sham group $(P<0.05)$. The representative images of the histological sections of the rabbit lungs were shown in Figure 3. Thus, while the regimens used in OLV groups III and IV were better than those in OLV groups II and I in terms of the severity of lung injury, they also generated a certain level of lung damage. 


\section{Liu et al.}

Table 2. Comparison of concentration of TNF-a, IL-8, SPA and lung injury score among five groups

\begin{tabular}{|c|c|c|c|c|c|c|}
\hline Variable & $\begin{array}{l}\text { Sham } \\
\text { group }\end{array}$ & $\begin{array}{l}\text { Upper left } \\
\text { lung } \\
\text { of OLV } \\
\text { group I }\end{array}$ & $\begin{array}{l}\text { Upper right } \\
\text { lung of } \\
\text { OLV group } \\
\text { I }\end{array}$ & $\begin{array}{l}\text { Upper left } \\
\text { lung } \\
\text { of OLV } \\
\text { group II }\end{array}$ & $\begin{array}{l}\text { Upper left } \\
\text { lung } \\
\text { of OLV } \\
\text { group III }\end{array}$ & $\begin{array}{l}\text { Upper left } \\
\text { lung } \\
\text { of OLV } \\
\text { group IV }\end{array}$ \\
\hline TNF- $\alpha(\mathrm{ng} / \mathrm{l})$ & $96.64 \pm 7.88$ & $176.63 \pm 5.79^{*}$ & $152.36 \pm 8.07$ *\# & $165.97 \pm 9.96^{* \#}$ & $153.43 \pm 8.49 * * \%$ & $148.70 \pm 7.32 * \# \%$ \\
\hline $\mathrm{IL}-8(\mathrm{pg} / \mathrm{ml})$ & $145.69 \pm 16.21$ & $238.72 \pm 16.18^{*}$ & $193.04 \pm 22.23 * \#$ & $212.02 \pm 17.26^{\text {*\# }}$ & $167.71 \pm 20.54 * \%$ & $159.21 \pm 18.13^{* \# \%}$ \\
\hline $\mathrm{SPA}(\mathrm{ng} / \mathrm{ml})$ & $91.72 \pm 4.81$ & $49.64 \pm 4.72 *$ & $58.60 \pm 8.73^{* \#}$ & $58.80 \pm 4.65^{* \#}$ & $68.96 \pm 4.90^{* \# \%}$ & $72.47 \pm 8.99 * \# \%$ \\
\hline Lunginjuryscore & $3.13 \pm 1.02$ & $9.65 \pm 0.43 *$ & $6.56 \pm 1.01$ *\# & $8.15 \pm 0.96^{\text {*\# }}$ & $6.36 \pm 0.88^{* * * \%}$ & $6.04 \pm 0.93^{* * \%}$ \\
\hline
\end{tabular}

Values are presented as mean \pm SD ( $n=8$ /group except $n=6$ for OLV I and 7 for OLV III); the lung injury score were evaluated by collapse of the lung, alveolar wall hyaline membrane formation, neutrophil infiltration or aggregation and alveolar congestion or hemorrhage as described in the methods. ${ }^{*} \mathrm{P}<0.05$ vs. sham group $\# \mathrm{P}<0.05$ vs. upper left lung in OLV group I; \% $\% 0.05$ vs. OLV group II. Tumor necrosis factor-alpha=TNF- $\alpha$; pulmonary surfactant protein $\mathrm{A}=\mathrm{SPA}$; interleukin-8=IL-8.
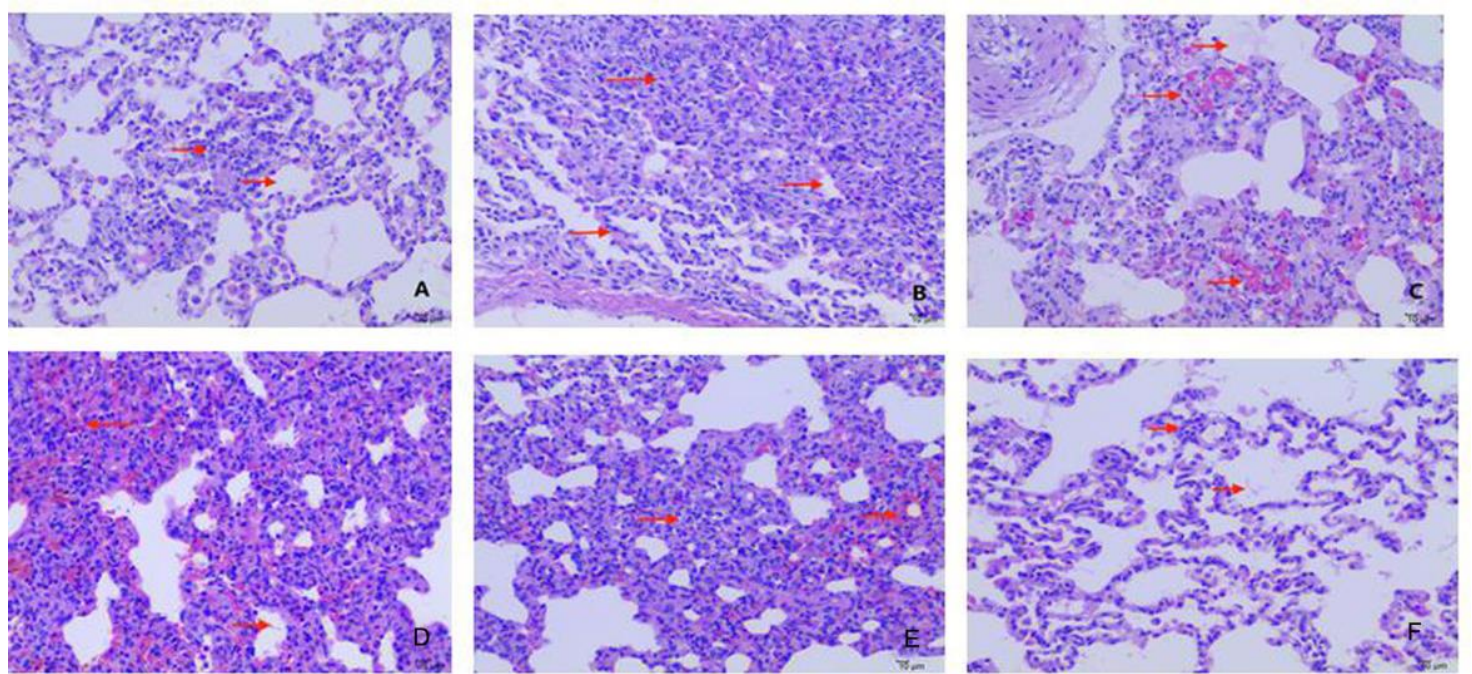

Figure 3. Representative images of H\&E staining of rabbit lungs under a light microscope. A total of 40 rabbits were divided randomly into 5 groups ( $n=8$ per group): a sham group, OLV group I, OLV group II, OLV group III and OLV group IV. Sections of the tissues in (A) sham group, (B) upper left lung from OLV group I, (C) upper right lung from OLV group I, (D) OLV group II, (E) OLV group III and (F) OLV group IV were subject to H\&E staining. Magnification, 400x. Red arrows indicate the pathological changes in the tissue.

\section{DISCUSSION}

The goal of the present study was to determine whether injury of the unventilated contralateral lung caused by OLV could be reduced by strategic ventilation. The main finding from this study was that OLV groups III and IV generated less inflammatory responses and less severe injury in the unventilated contralateral lung compared with groups I and II. Given the main differences in the regimens of these groups were decreased VT and increased PEEP in OLV group III/IV, compared with OLV group I, we conclude that reduced VT and increased PEEP may both ameliorate the OLV-induced injury to the unventilated contralateral lung. The OLVinduced lung injury is influenced by several factors. For instance, a relatively larger VT during OLV may produce a higher direct pressure, easily leading to lung injury, while a low VT is thought to result in lesser injury (Moriondo et al., 2007). Moreover, the non- 
ventilated lung collapses cause lung damage through ischemia/reperfusion (I/R) injury (Sivrikoz et al., 2002; Funakoshi et al., 2004).

In addition, a high concentration of oxygen, which is used for avoiding hypoxemia during OLV, can generate additional oxygen free radicals (Grocott, 2008; De Conno et al., 2009). In addition, previous studies have shown that the lung injury induced by hypoxemia was more likely to occur with OLV than TLV (Ferreira et al., 2011; Jorgenson et al., 2011). Finally, the shear force generated by the closure and expansion of the alveolar spaces can also aggravate lung injury (Lohser and Slinger, 2015). Amounts of VCV with adjusted VT, PEEP and $\mathrm{F}_{\mathrm{I}} \mathrm{O}_{2}$ applied in this study were decided based on the values used in clinical practice.

We also used a rabbit model with ventilated right and collapsed left lung in this investigation, which was widely used in the OLV study (Xu et al., 2016; Tsai et al., 2009). Moreover, we compared the levels of pro-inflammatory factors such as TNF- $\alpha$ and IL-8 as indicators of severity of inflammation, as they play important roles in mediating epithelial and endothelial injuries in the lungs (Ando et al., 2012; Madl et al., 2014; Aschner et al., 2014; Zhu et al., 2017).

We observed that the concentrations of TNF- $\alpha$ and IL- 8 in BALF increased significantly in the ventilated lung, compared to the sham group as expected, while that of SPA decreased. SPA is mainly produced by type II alveolar epithelial cells and it reduces the surface tension of the lung alveolar liquid interface, improves alveolar stability and prevents the expiratory alveolar collapse (Matsumoto et al., 2005; Yehuda et al., 2015). Thus, the severity of lung injury can be evaluated by the changes in the levels of these pro-inflammatory factors as well as the levels of SPA (Ryu et al., 2011; Linder and Russell, 2014).

Although controversial, their studies showed that injury in non-ventilate was more serious than that in the ventilated lung after OLV (Koertke et al., 2010). Consistent with this, we also found that the concentration of TNF- $\alpha$, IL- 8 and SPA in the non-ventilated left lung were all higher than those in the ventilated right lung. These observations were further supported by the semiquantitative lung injury scores in ventilated and non-ventilated lungs. However, one previous study (Zingg et al., 2010) on the ventilated left and collapsed right lung during esophagectomy for cancer found the opposite, where the inflammatory response in the ventilated lung was more severe than that in the collapsed lung. This discrepancy may be due to several factors. First, the OLV models used in the two studies were different. The previous observation was from on the OLV on the cancer patients (Zingg et al., 2010), while we used a rabbit OLV model. Second, that study examined 36 elderly human patients, while our study was conducted on 20month-old rabbits as a model for OLV.

In our study, the injury in the unventilated contralateral lung was reduced by a lower VT and higher PEEP used in ventilating the other lung. The OLV group II with a VT of $8 \mathrm{~mL} / \mathrm{kg}$ had lower concentrations of TNF- $\alpha$, IL- 8 and lower lung injury score than in the OLV group I with a VT of $10 \mathrm{~mL} / \mathrm{kg}$. This suggested that a smaller VT not only reduced the pulmonary pressure in the ventilated side, but also ameliorated the inflammatory response in the non-ventilated contralateral lung. Similarly, the application of PEEP in the OLV groups II and III also benefited the non-ventilated contralateral lung, in line with previous studies showing that PEEP prevented the atelectasis during OLV and reduced lung injury (Lohser and Slinger, 2015; Guldner et al., 2015).

Compared with OLV group I, the OLV group IV had significantly lower concentrations of TNF- $\alpha$, IL-8 and lower lung injury score, indicating that non-ventilated lung injury was reduced when a smaller VT and decreased $\mathrm{F}_{\mathrm{I}} \mathrm{O}_{2}$ were applied along with PEEP. However, there were no differences in the levels of TNF- $\alpha$, IL- 8 and the lung injury score between OLV groups III and $\mathrm{IV}$, and the only difference in the regimen used in these two groups was the value of $\mathrm{F}_{\mathrm{I}} \mathrm{O}_{2}$. Thus, we reckoned that the $20 \%$ difference in $\mathrm{F}_{\mathrm{I}} \mathrm{O}_{2}$ did not significantly contribute to the protection from OLV-induced lung injury.

Although lung injury occurred during OLV, the arterial blood gas values (such as $\mathrm{pH}, \mathrm{PaO}_{2}$, $\mathrm{PaCO}_{2}$ and $\mathrm{SaO}_{2}$ ) did not directly correlate with lung injury. This may be because first, the OLV rabbit model was generated from the normal rabbits, without any lung disease or acid-base disorders; second, because of compensatory 
capacity, the changes in the arterial blood gas may not immediately reflect in the downstream lung damage; third, we prioritized early intervention and treatment with oxygenation. To avoid hypoxia and the consequent reaction, TLV was implemented during OLV when the $\mathrm{SaO}_{2}$ was lower than $80 \%$.

The $\mathrm{PaO}_{2}$ at $2 \mathrm{~h}$ and $3.5 \mathrm{~h}$ after the onset of trial in the sham group was lower than all of the OLV groups, and that may be because the fresh air was used in the rabbits of the sham group, whereas $80 \%$ oxygen was administered to the rabbits of the OLV groups. In addition, although at $2 \mathrm{~h}$ after the onset of trial, the $\mathrm{SaO}_{2}$ in OLV group I was lower than that in groups II, III, IV and the sham group, the difference was not statistically significant. Based on these observations, we propose that the arterial blood gas parameters were not suitable indictors of lung injury during $\mathrm{OLV}$, at least within the short period of time after the initiation of the OLV procedure.

Limitations of this study include the following. First, in clinic, in addition to the VCV used in our study, several other ventilation approaches, such as pressure-controlled ventilation (PCV), conventional ventilation (CV), protective ventilation (PV), and medical intervention (Liu et al., 2016) are used. Therefore, strategic ventilation for other approaches should also be tested in this animal model. Second, our study suggested that a decrease in $\mathrm{F}_{\mathrm{I}} \mathrm{O}_{2}$ alone generated a certain degree of lung injury.

However, this was accompanied by the frequent dropping of $\mathrm{SaO}_{2}$ below $80 \%$ and therefore, repeated TLV, instead of constant OLV. Therefore, we plan to examine the protective effects of only modulating $\mathrm{F}_{\mathrm{I}} \mathrm{O}_{2}$ on the nonventilated lung. In the present study, we report that strategic ventilation can reduce the inflammatory response and injury in the nonventilated contralateral lung during OLV. We believe that a relatively smaller VT and higher PEEP may play a role in this protection.

This work was supported by the Teachers' talent pool of Shanghai University of Medicine \& Health Sciences (2019).

\section{REFERENCES}

AMATO, M.B.; BARBAS, C.S.; MEDEIROS, D.M. et al. Effect of a protective-ventilation strategy on mortality in the acute respiratory distress syndrome. N. Engl. J. Med., v.338, p.347-354, 1998.

ANDO, K.; DOI, T.; MOODY, S.Y. et al. The effect of comorbidity on the prognosis of acute lung injury and acute respiratory distress syndrome. Intern. Med., v.51, p.1835-1840, 2012.

ASCHNER, Y.; ZEMANS, R.L.; YAMASHITA, C.M. et al. Matrix metalloproteinases and protein tyrosine kinases: potential novel targets in acute lung injury and ARDS. Chest, v.146, p.10811091, 2014.

BENUMOF, J.L. One-lung ventilation and hypoxic pulmonary vasoconstriction: implications for anesthetic management. Anesth. Analg., v.64, p.821-833, 1985.

BRODSKY, J.B. The evolution of thoracic anesthesia. Thorac. Surg. Clin., v.15, p.1-10, 2005.

BRODSKY, J.B.; FITZMAURICE, B. Modern anesthetic techniques for thoracic operations. World J. Surg., v.25, p.162-166, 2001.

BROWER, R.G.; MATTHAY, M.A. et al. Ventilation with lower tidal volumes as compared with traditional tidal volumes for acute lung injury and the acute respiratory distress syndrome. N. Engl. J. Med., v.342, p.1301-1308, 2000. (Acute respiratory distress syndrome network).

BRUN-BUISSON, C.; MINELLI, C.; BERTOLINI, G. et al. Epidemiology and outcome of acute lung injury in European intensive care units: results from the ALIVE study. Intens. Care Med., v.30, p.51-61, 2004.

CAMPOS, J.H. Current techniques for perioperative lung isolation in adults. Anesthesiology, v.97, p.1295-1301, 2002.

DE CONNO, E.; STEURER, M.P.; WITTLINGER, M. et al. Anesthetic-induced improvement of the inflamematory response to one-lung ventilation. Anesthesiology, v.110, p.1316-1326, 2009. 
DELLINGER, R.P.; CARLET, J.M.; MASUR, H. et al. Surviving sepsis campaign management guidelines committee. Surviving sepsis campaign guidelines for management of severe sepsis and septic shock. Crit. Care Med., v.32, p.858-873, 2004.

EGUCHI, T.; HAMANAKA, K.; KONDO, R. et al. Lung re-expansion following one-lung ventilation induces neutrophil cytoskeletal rearrangements in rats. Ann. Thorac. Cardiovasc. Surg., v.20, p.276-283, 2014.

FERREIRA, H.C.; MAZZOLI-ROCHA, F.; MOMESSO, D.P. et al. On the crucial ventilatory setting adjustment from two-to onelung ventilation. Respir. Physiol. Neurobiol., v.179, p.198-204, 2011.

FUNAKOSHI, T.; ISHIBE, Y.; OKAZAKI, N. et al. Effect of re-expansion after short-period lung collapse on pulmonary capillary permeability and pro-inflammatory cytokine gene expression in isolated rabbit lungs. $\mathrm{Br} . \mathrm{J}$. Anaesth., v.92, p.558-563, 2004.

GROCOTT, H.P. Oxygen toxicity during onelung ventilation: is it time to re-evaluate our practice? Anesthesiol. Clin., v.26, p.273-280, 2008.

GÜLDNER, A.; KISS, T.; SERPA NETO, A. et al. Intraoperative protective mechanical ventilation for prevention of postoperative pulmonary complications: a comprehensive review of the role of tidal volume, positive endexpiratory pressure, and lung recruitment maneuvers. Anesthesiology, v.123, p.692-713, 2015.

JORGENSON, A.; JAEGER, J.M.; SOUZA, D.G. et al. Acute intra-operative pulmonary embolism: an unusual cause of hypoxemia during one-lung ventilation. J. Cardiothorac. Vasc. Anesth., v.25, p.1113-1115, 2011.

KALLET, R.H.; MATTHAY, M.A. Hyperoxic acute lung injury. Respir. Care, v.58, p.123-141, 2013.

KARZAI, W.; SCHWARZKOPF, K. Hypoxemia during one-lung ventilation: prediction, prevention, and treatment. Anesthesiology, v.110, p.1402-1411, 2009.

KESZLER, M. Mechanical ventilation strategies. Semin. Fetal. Neonatal. Med., v.22, p.267-274, 2017.
KOERTKE, H.; ZITTERMANN, A.; WAGNER, O. et al. Efficacy and safety of very low-dose self-management of oral anticoagulation in patients with mechanical heart valve replacement. Ann. Thorac. Surg., v.90, p.14871493, 2010.

KOZIAN, A.; SCHILLING, T.; FREDÉN, F. et al. One-lung ventilation induces hyperperfusion and alveolar damage in the ventilated lung: an experimental study. Br. J. Anaesth., v.100, p.549-559, 2008.

KUIPERS, M.T.; ASLAMI, H.; JANCZY, J.R. et al. Ventilator-induced lung injury is mediated by the NLRP3 inflammasome. Anesthesiology, v.116, p.1104-1115, 2012.

LINDER, A.; RUSSELL, J.A. An exciting candidate therapy for sepsis: ulinastatin, a urinary protease inhibitor. Intensive Care Med., v.40, p.1164-1167, 2014.

LIU, Z.; HE, W.; JIA, Q. et al. A comparison of extraluminal and intraluminal use of the Uniblocker in left thoracic surgery: a Consortcompliant article. Medicine, v.96, p.e6966, 2017.

LIU, Z.; LIU, X.; HUANG, Y. et al. Intraoperative mechanical ventilation strategies in patients undergoing one-lung ventilation: a meta-analysis. Springerplus, v.5, p.1251, 2016.

LOHSER, J.; SLINGER, P. Lung injury after one-lung ventilation: a review of the pathophysiologic mechanisms affecting the ventilated and the collapsed lung. Anesth. Analg., v.121, p.302-318, 2015.

MADL, A.K.; PLUMMER, L.E.; CAROSINO, C. et al. Nanoparticles, lung injury, and the role of oxidant stress. Ann. Rev. Physiol., v.76, p.447$465,2014$.

MATSUMOTO, K.; AKAO, Y.; OHGUCHI, K. et al. Xanthones inducecell-cycle arrest and apoptosis in human colon cancer DLD-1cells. Bioorg. Med. Chem., v.13, p.6064-6069, 2005.

MORIONDO, A.; PELOSI, P.; PASSI, A. et al. Proteoglycan fragmentation and respiratory mechanics in mechanically ventilated healthy rats. J. Appl. Physiol., v.103, p.747-756, 2007.

RYU, H.W.,; CHO, J.K.; CURTIS-LONG, M.J. et al. $\alpha$-Glucosidase inhibition and antihyperglycemic activity of prenylated xanthonesfrom Garcinia mangostana. Phytochemistry, v.72, p.2148-2154, 2011. 
SADDY, F.; OLIVEIRA, G.P.; GARCIA, C.S. $e t$ al. Assisted ventilation modes reduce the expression of lung inflammatory and fibrogenic mediators in a model of mild acute lung injury. Intensive Care Med., v.36, p.1417-1426, 2010.

SIVRIKOZ, M.C.; TUNÇÖZGÜR, B.; CEKMEN, M. et al. The role of tissue reperfusion in the reexpansion injury of the lungs. Eur. J. Cardiothorac. Surg., v.22, p.721-727, 2002.

TREMBLAY, L.N.; SLUTSKY, A.S. Ventilatorinduced lung injury: from the bench to the bedside. Intensive Care Med., v.32, p.24-33, 2006.

TSAI, J.A.; LUND, M.; LUNDELL, L. et al. One-lung ventilation during thoracoabdominal esophagectomy elicits complement activation. $J$. Surg. Res., v.152, p.331-337, 2009.
XU, Z.P.; GU, L.B.; BIAN, Q.M. et al. A novel method for right one-lung ventilation modeling in rabbits. Exp. Ther. Med., v.12, p.1213-1219, 2016.

YEHUDA, I.; MADAR, Z.; LEIKINFRENKEL, A. et al. Glabridin, an isoflavan from licorice root, downregulates iNOS expression and activity under high-glucose stress and inflammation. Mol. Nutr. Food Res., v.59, p.1041-1052, 2015.

ZHU, Q.; HE, G.; WANG, J. et al. Downregulation of toll-like receptor 4 alleviates intestinal ischemia reperfusion injury and acute lung injury in mice. Oncotarget, v.8, p.1367813689, 2017.

ZINGG, U.; FORBERGER, J.; FREY, D.M. et $a l$. Inflammatory response in ventilated left and collapsed right lungs, serum and pleural fluid, in transthoracic esophagectomy for cancer. Eur. Cytokine Netw., v.21, p.50-57, 2010. 